\title{
First Maps for the Systematic Registration of Property in the Kingdom of Romania
}

\author{
Doina VASILCA ${ }^{1^{*}}$ \\ ${ }^{1}$ Faculty of Geodesy. Technical University of Civil Engineering Bucharest, Romania. \\ *)Corresponding author, e-mail: doinavasilca@yahoo.com
}

BulletinUASVM Horticulture 73(2) / 2016

Print ISSN 1843-5254, Electronic ISSN 1843-5394

DOI:10.15835/buasvmcn-hort:11624

\begin{abstract}
In this article are presented the very first maps realised in a systematic way in order to determine the boundaries and register the properties of the Kingdom of Romania, at a scale of 1:20,000 in the equal-area pseudoconical Bonne projection. This projection was not applied in a uniform way for the whole territory of the country, but differently for the areas situated east and west of the Zimnicea meridian. For each of these two zones, the peculiarities of applying the Bonne projection were shown. Furthermore, the means of establishing the nomenclatures of the maps at a scale of 1:20,000, but also at smaller scales of 1:50,000, 1:100,000 and 1:200,000 were explained in detail. Since the analyzed map projection preserves area measurements, this property was verified on five maps at the scale of 1:20,000, chosen from both zones. Results obtained for the zone east of the Zimnicea meridian showed a $0.0005 \%$ difference, falling within the tolerated error, but for the maps situated west of the Zimnicea meridian, the area differs by about $3 \%$. It was proven that this large difference in the area of the analyzed maps, identified at the eastern extremity of the mapped zone, is due to the fact that they are not actually bordered by the Zimnicea meridian, but by a line related to the Cartesian system used. The Bonne projection maps made for the entire Romanian Kingdom by specialists of the Romanian Army nowadays possess significant historical importance, both in terms of mapping and cadastre.
\end{abstract}

Keywords: equal-area Bonne projection, map nomenclature, property registration

\section{INTRODUCTION}

Until 1873, our country did not possess a topographic map uniformly created for its entire territory. A map was drawn in Wallachia between the years 1855 and 1857, during the reign of the Prince Barbu Stirbey, by the Austrian Army, under Marshal Fligely (Buchholtzer and Rotaru, 1937; Dragomir and Rotaru, 1986). The map featured 112 cartographical sheets at a scale of 1:57,600, realized using the Cassini cylindrical transverse projection, also known as Cassini-Soldner projection (Bartos-Elekes, 2010; Bartos-Elekes et al., 2013).

In Moldavia, the situation was even worse, since there the latest map dated from 1769, as drawn by the Russian Army during the RussoTurkish War (Buchholtzer and Rotaru, 1937). This map, realised under expeditious methods caused by the war, was, needless to say, not accurate.
Given the conditions of that time, and because on $12^{\text {th }}$ November 1859 the General Staff Corps (Corpul de Stat Major General) was founded, possessing trained personnel in Astronomy, Geodesy and Topography in addition to realising military maps, it proved desirable to also draw the cadastral map of the country (Rotaru et al., 1989).

Surveys for this map started in 1873 in the north of Moldavia and were finalised in 1902 in Wallachia, up to the Zimnicea meridian, having being interrupted between 1876 and 1880 because of the Russo-Turkish War (Buchholtzerand Rotaru, 1937). In Dobruja, surveys were made between 1880 and 1884, while between 1900 and 1914, western Wallachia and Oltenia were also surveyed (Rotaru et al., 1989).

However, the map was not uniformly realised for the entire country. The territory was divided into two areas through the $\mathrm{l}=23^{\circ}$ east Paris 


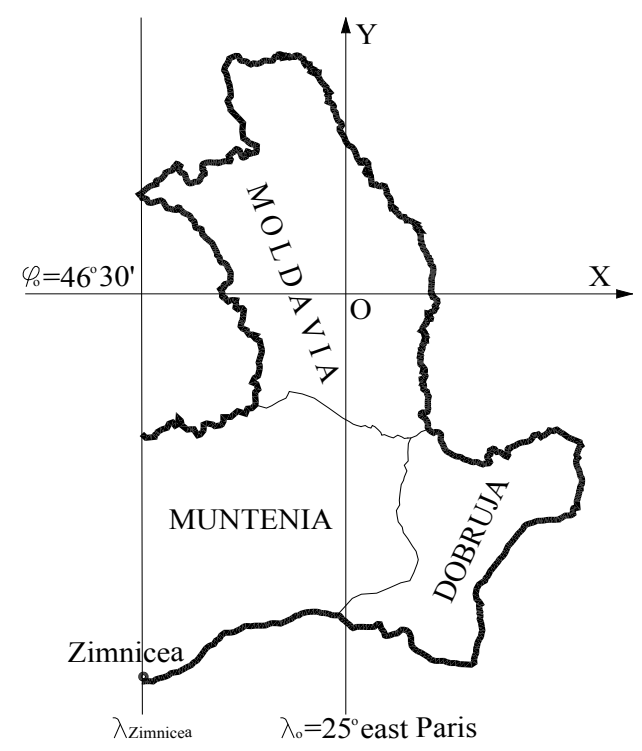

Fig. 1. The Cartesian system for Moldavia, Dobruja and Wallachia east of the Zimnicea meridian

meridian, which passes near Zimnicea and was, for this reason, named the "Zimnicea" meridian.

The pseudoconical Bonne projection was chosen because it is an equal-area projection, thus proving useful in cadastre. This map projection was applied as following (Munteanu, 2003):

1 . For the area situated east of the Zimnicea meridian, meaning Moldavia, Eastern Wallachia and Dobruja (after its annexation to Romania as a result of the Treaty of Berlin from 1878), the drawn map had the following characteristics:

- The Bessel ellipsoid (1841) was used as the reference ellipsoid

- The Cartesian coordinate system had as the OY axis the plane image of the $\mathrm{l}_{\mathrm{o}}=25^{\circ}$ east Paris meridian, having the positive direction to the North. The OX axis, with the positive direction to the East, was tangent to the $\mathrm{j}_{0}=46^{\circ} 30^{\prime}$ parallel (Fig. 1).

2. For Wallachia to the west of the Zimnicea meridian and Oltenia, the map had the following characteristics:

- The Clarke ellipsoid (1880) was used.

- The Cartesian coordinate system was defined as following: the $O Y$ axis was the plane image of the Bucharest meridian, namely $\mathrm{l}_{\mathrm{o}}=23^{\circ} 46^{\prime} 27^{\prime \prime} .85$ east Paris (Rotaru et al., 1989). The OY axis was oriented towards north. The OX axis, having the positive direction to East,

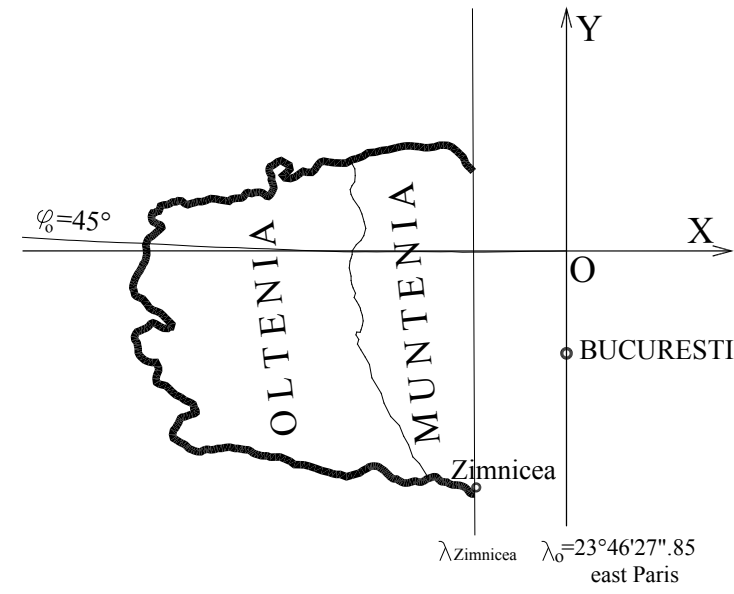

Fig. 2. The Cartesian coordinate system for Wallachia west of the Zimnicea meridian and Oltenia

was represented by the tangent line to the $\mathrm{j}_{\mathrm{o}}=45^{\circ}$ parallel (Fig. 2).

\section{MATERIALS AND METHODS}

In order to accomplish this research, we analysed 1:20,000 scale map sheets for zones situated both east and west of the Zimnicea meridian found in the archive of the "General de divizie Constantin Barozzi" Topographical Military Directorate in Bucharest. These are: 48 Series - A' Column and XLVII Series- A' Column for the Eastern area, and 47 Series- P Column- Q Column, XLVIII Series- P Column- Q Column and 49 SeriesP Column - Q Column for the Western area. It also made use of a 1:1,600,000 scale index map for the entire country.

To describe the content of the map sheets, we used an atlas of conventional signs, edited in 1890 specifically for these maps, namely the Atlas portativ de semne conventionale adoptate pentru harta tarii 1:20,000 si ridicari militare (Portable atlas of conventional signs adopted for the $1: 20,000$ scale country map and military surveys).

The description of the means through which the nomenclature was established for the Bonne projection map sheets at a scale of $1: 20,000$, and at smaller scales, was based on the 1:1,600,000 index map. 


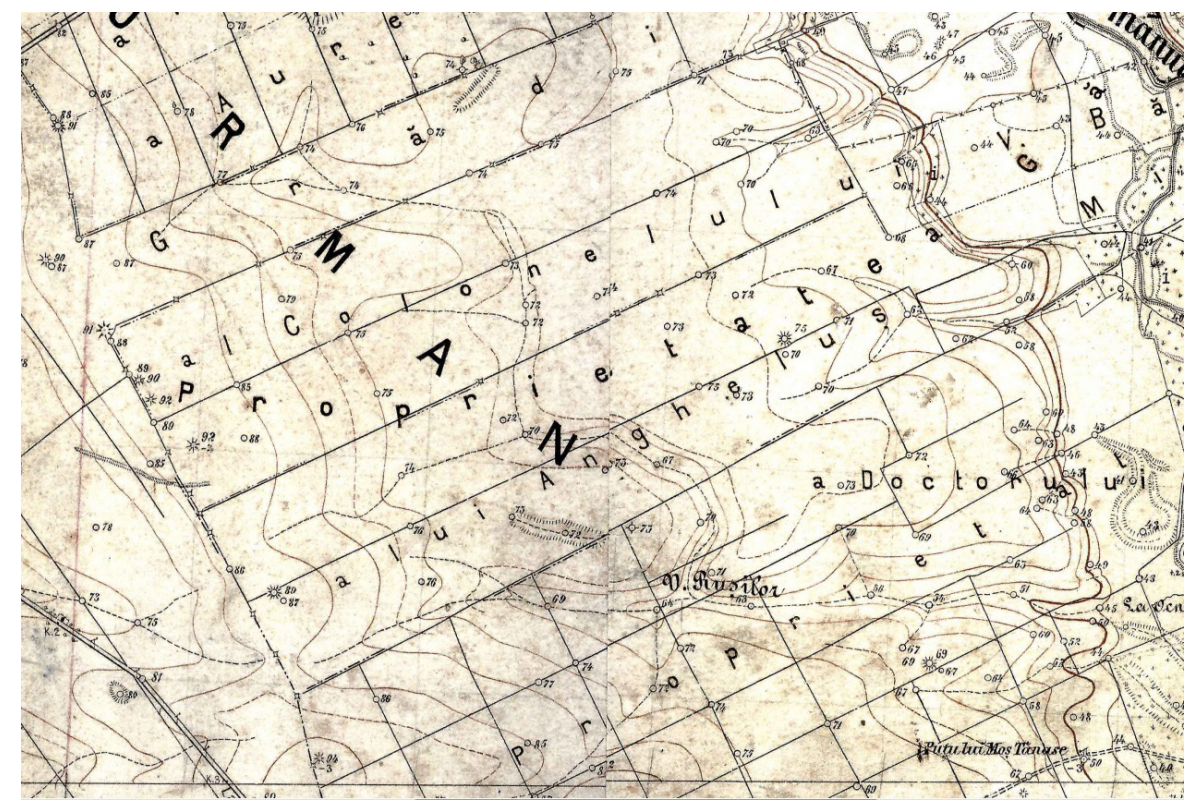

Fig. 3. Detail of the XLVII Series- $A^{\prime}$ Column map sheet showing the property registration

To verify if the surface areas written on the maps were equal with the corresponding areas on the ellipsoid, thus respecting the main characteristic of the projection, we used the equation for the area of a trapezium whose sides were represented by the arcs of meridians and parallels.

\section{RESULTS AND DISCUSSIONS}

\section{Map Features for the Two Areas}

\section{Moldavia, Dobruja, and Wallachia east of the Zimnicea meridian}

The dimensions of the map sheets were 10 $\mathrm{km} \times 10 \mathrm{~km}$, the edges of the frame being parallels to the OX and OY axes. There were no coordinates written on the map frame, therefore the trapezium position determination could only be made based on the index map.

Regarding the content of the map, it included: relief, hydrographic features, vegetation, cities, towns, villages, roads, railroads, administrative boundaries and properties with their lines, as well as names and owners (Fig. 3). The maps were realised in two colours: black and sepia.

Outside of the map neatline, one could find the following elements: on the northern side, the zone and the column that make up the map sheet nomenclature; on the southern side, the name of the person who wrote the map and the year of its drawing; on the western side, the names of the persons who realised and checked the map, as well as the chiefs of the Geodesy and Topography Departments of the Army Geographical Institute (Institutul Geografic al Armatei), ending with the name of the institution's executive. The year when the map was made and the scale were also written below. On some map sheets, underneath this information, there were drawn on a larger scale details of some properties, while on the western side of others, information regarding elevation mismatches between neighbouring map sheets was inscribed, where appropriate.

Further outside of the map frame, there also appear trigonometric points on all sides, covering planimetric details, station points and large natural mounds, all stemming from neighbouring maps.

\section{Wallachia west of the Zimnicea meridian and Oltenia}

The neatline of these maps was formed by the lines of latitude and longitude. The dimension of map sheets was $10^{c} \times 10^{c}$, with the exception of those delineated east of the Zimnicea meridian. These map sheets had the same dimension on latitude, but they were wider on longitude. In the South, precisely from $j=48^{\mathrm{G}} 40^{\mathrm{c}}$ to $\mathrm{j}=49^{\mathrm{G}} 60^{\mathrm{c}}$, they contained the entire P column and a portion of the $Q$ column, while in the North, between latitudes $j=$ 


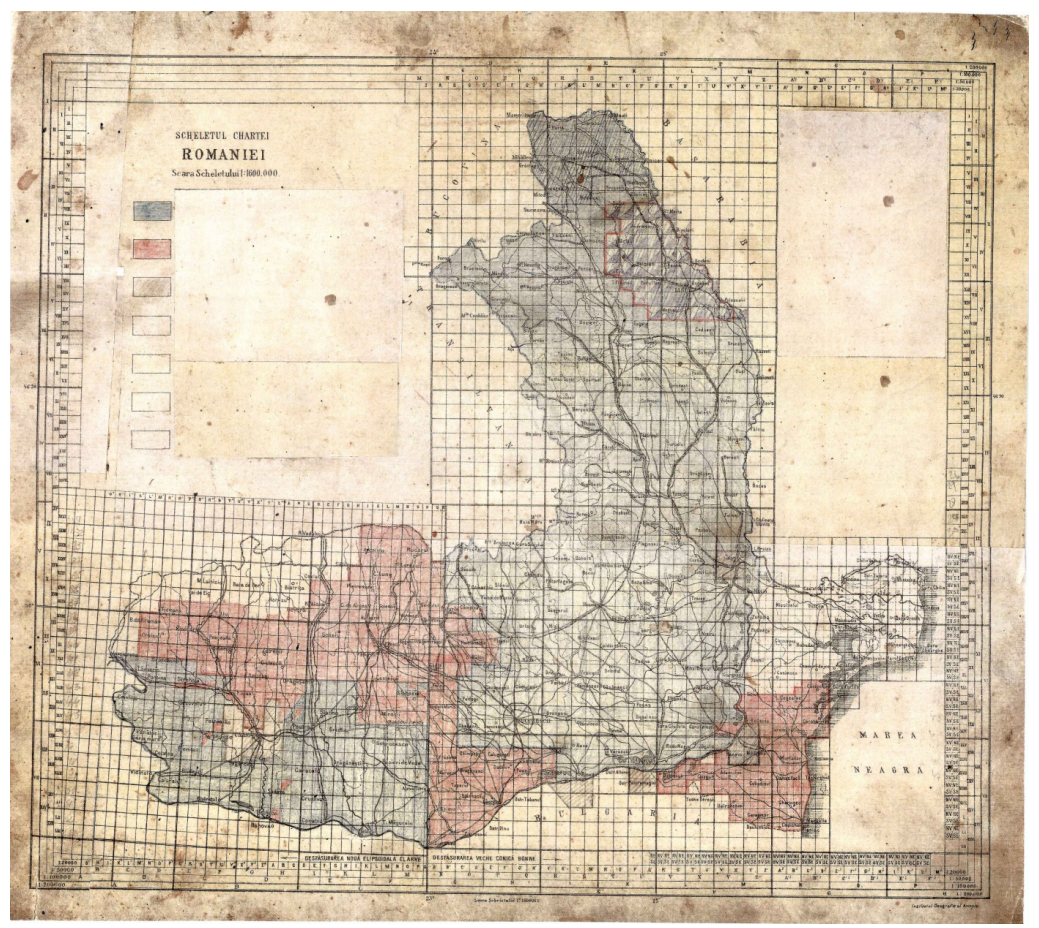

Fig. 4. The 1,600,000 scale index map

Each map sheet could be identified by the letter representing the column and the zone number (Fig. 5).

$49^{\mathrm{G}} 60^{\mathrm{c}}$ and $\mathrm{j}=50^{\mathrm{G}} 70^{\mathrm{c}}$, they contain the $\mathrm{Q}$ column entirely and a portion of the R column.

The meridian of latitude $l_{\text {Bucharest }}-1^{\mathrm{G}}$ separated the $\mathrm{O}$ and $\mathrm{P}$ columns.

The zones covering the territory were numbered from XXXI in the North to LIII in the South. The parallel of latitude $50^{\mathrm{G}}$ separated the XXXVII and XXXVIII zones.

The values of latitudes, expressed in the centesimal system, were written at the corners of the map sheets, while for longitude, these were written only in centigrads, such that the longitude values could be determined only by using the index map.

Regarding the content of these maps, it was the same as the maps depicting the area east of the Zimnicea meridian.

On all maps located both to the east and west of the Zimnicea meridian, details were also drawn on a $0.5 \mathrm{~cm}$ strip outside the neatline, for connecting with neighbouring maps.

With respect to the map's additional elements represented outside the neatline, they were far less than those found on maps to the east of the Zimnicea meridian. Thus, on each side their dimensions were written in meters. Below the southern side, the area of the represented surface was written in hectares (with two decimal places), alongside the names of the persons who realised and checked the map. On the east side there can be found information regarding the maps' levelling connection.

\section{The Nomenclature of the Bonne Projection Map Sheets, as Used in Our Country}

In order to describe the manner of establishing the nomenclature, we used an index map at the 1:1,600,000 scale (Fig. 4).

Based on the topographic survey and the 1:20,000 scale maps, maps at smaller scales, namely $1: 50,000,1: 100,000$ and 1:200,000, were later created. The nomenclatures for these maps were established as following:

\section{The 1:50,000 scale}

1. Moldavia, Dobruja, and Wallachia east of the Zimnicea meridian

The territory was divided in columns and zones by parallels drawn every $20 \mathrm{~km}$ to the OX and OY coordinate axes. Thus, four trapezia at the $1: 20,000$ scale formed a trapezium at the 50,000 scale. Doing so netted 18 columns denoted by letters from $\mathrm{N}$ to $\mathrm{Z}$, starting from the meridian of 


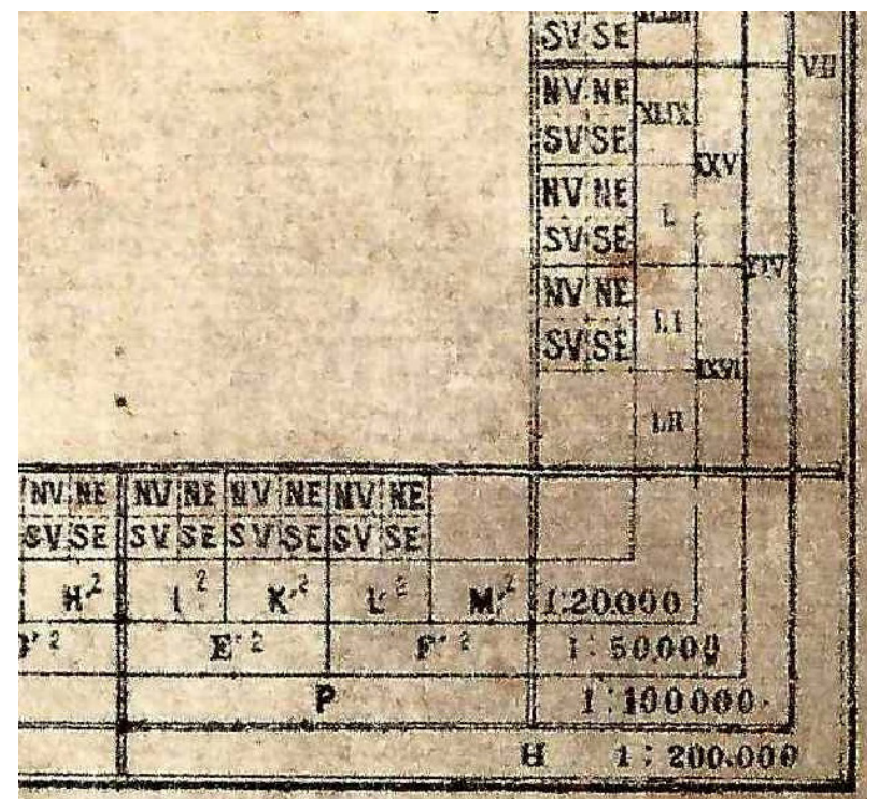

Fig. 5. Detail from the 1,600,000 scale index map

longitude $\mathrm{l}=23^{\circ}$ east Paris and continuing with $\mathrm{A}^{\prime 2}$, $\mathrm{B}^{\prime 2}, \ldots, \mathrm{F}^{2}$. Twenty six zones, numbered from North to South by Roman numerals, from I to XXVI, were obtained as well.

2. Wallachia west of the Zimnicea meridian and Oltenia

For this area, the territory was divided by meridians from $30^{c}$ to $30^{c}$ in 11 columns, meaning that each column at the 1:50,000 scale contained tree columns at the 1:20,000 scale. These were denoted from East to West with letters starting from $\mathrm{B}$ to $\mathrm{M}$, excluding J. Zones were delineated by the parallels from $20^{c}$ to $20^{c}$, meaning that a zone at the 1:50,000 scale consisted of two zones at 1:20,000 scale. These were numbered from North to South using Roman numerals starting from XV to XXVI. Thus, a trapezium at the 1:50,000 scale contained six trapezia at the 1:20,000 scale.

\section{The 1:100,000 map scale}

Two columns at the 1:50,000 scale formed a column at the 1:100,000 scale and similarly, two zones at the 1:50,000 scale formed a zone at the 1:100,000 scale. Columns were denoted with capital letters as following: from A to $\mathrm{F}$ for Wallachia west of the Zimnicea meridian and Oltenia and from G to P, excluding J, for Moldavia, Dobruja, and Wallachia east of the Zimnicea meridian. Zones were numbered from North to South using Roman numerals from II to XIV for Moldavia, Dobruja and Wallachia east of the Zimnicea meridian, and from IX to XIV for Wallachia west of the Zimnicea meridian and Oltenia.

In this way, four trapezia at the $1: 50,000$ scale formed a trapezium at the 1:100,000 scale, its nomenclature composed of the column name and the zone number.

\section{The 1:200,000 map scale}

Similarly, two columns at a scale of 1:100,000 formed a column at the 1:200,000 scale and two zones at the scale 1:100,000 formed a zone at the $1: 200,000$ scale. Columns were denoted by capital letters from East to West (from A to C for Wallachia west of the Zimnicea meridian and Oltenia, and from D to H for Moldavia, Dobruja, and Wallachia east of the Zimnicea meridian). Thus four trapezia at the 1:100,000 scale formed a trapezium at $1: 200,000$ scale, its nomenclature consisting of the column name and the zone number.

\section{Study of Equal-Area Representation of Surfaces on a Plane}

Considering the fact that the analysed maps were made in the pseudo-conical equal-area Bonne projection, this was intended to check if the area represented on these maps was equal to the corresponding area on the ellipsoid. Thus, their areas were calculated based on coordinates determined for the trapezia corners.

Because the Bonne projection was not applied in an uniform way for the entire country, the 
Tab. 1. Coordinates of the map sheets corners and their areas (Moldavia, Dobruja, and Wallachia east of the Zimnicea meridian)

\begin{tabular}{|c|c|c|c|c|c|c|}
\hline Map sheet & $\mathrm{X}[\mathrm{m}]$ & $\mathrm{Y}[\mathrm{m}]$ & j & 1 & $\begin{array}{l}\text { Calculated } \\
\text { area }\left[\mathrm{km}^{2}\right]\end{array}$ & $\begin{array}{l}\text { Theoretical } \\
\text { area }\left[\mathrm{km}^{2}\right]\end{array}$ \\
\hline \multirow{4}{*}{$\begin{array}{l}48 \text { Series- } \\
A^{\prime} \text { Column }\end{array}$} & $-160,000$ & $-280,000$ & $44^{\circ} 06^{\prime} 21^{\prime \prime} .1062$ & $23^{\circ} 00^{\prime} 04^{\prime \prime} .0729$ & \multirow{4}{*}{100.0005} & \multirow{4}{*}{100.0000} \\
\hline & $-150,000$ & $-280,000$ & $44^{\circ} 06^{\prime} 29^{\prime \prime} .0224$ & $23^{\circ} 07^{\prime} 33^{\prime \prime} .6548$ & & \\
\hline & $-160,000$ & $-270,000$ & $44^{\circ} 11^{\prime} 45^{\prime \prime} .0270$ & $22^{\circ} 59^{\prime} 53^{\prime \prime} .1296$ & & \\
\hline & $-150,000$ & $-270,000$ & $44^{\circ} 11^{\prime} 52^{\prime \prime} .9555$ & $23^{\circ} 07^{\prime} 23^{\prime \prime} .3943$ & & \\
\hline \multirow{4}{*}{$\begin{array}{l}\text { XLVII Series -A' } \\
\text { Column }\end{array}$} & $-160,000$ & $-270,000$ & $44^{\circ} 11^{\prime} 45^{\prime \prime} .0270$ & $22^{\circ} 59^{\prime} 53^{\prime \prime} .1296$ & \multirow{4}{*}{100.0005} & \multirow{4}{*}{100.0000} \\
\hline & $-150,000$ & $-270,000$ & $44^{\circ} 11^{\prime} 52^{\prime \prime} .9555$ & $23^{\circ} 07^{\prime} 23^{\prime \prime} .3943$ & & \\
\hline & $-160,000$ & $-260,000$ & $44^{\circ} 17^{\prime} 08^{\prime \prime} .9422$ & $22^{\circ} 59^{\prime} 42^{\prime \prime} .1351$ & & \\
\hline & $-150,000$ & $-260,000$ & $44^{\circ} 17^{\prime} 16^{\prime \prime} .8832$ & $23^{\circ} 07^{\prime} 13^{\prime \prime} .0858$ & & \\
\hline
\end{tabular}

Tab. 2. Coordinates of the map sheet corners and their areas (Wallachia west of the Zimnicea meridian and Oltenia)

\begin{tabular}{|c|c|c|c|c|}
\hline Map sheet & $\mathrm{j}$ & l & $\begin{array}{c}\text { Calculated area } \\
{\left[\mathrm{km}^{2}\right]}\end{array}$ & $\begin{array}{c}\text { Area writen on the } \\
\text { map }\left[\mathrm{km}^{2}\right]\end{array}$ \\
\hline \multirow{4}{*}{$\begin{array}{l}49 \text { Series- } \\
\text { P-Q Column }\end{array}$} & $43^{\circ} 55^{\prime} 12^{\prime \prime}$ & $22^{\circ} 52^{\prime} 27^{\prime \prime} .85$ & \multirow{4}{*}{100.799} & \multirow{4}{*}{103.000} \\
\hline & $43^{\circ} 55^{\prime} 12^{\prime \prime}$ & $23^{\circ} 00^{\prime} 00^{\prime \prime} .00$ & & \\
\hline & $44^{\circ} 00^{\prime} 36^{\prime \prime}$ & $22^{\circ} 52^{\prime} 27^{\prime \prime} .85$ & & \\
\hline & $44^{\circ} 00^{\prime} 36^{\prime \prime}$ & $23^{\circ} 00^{\prime} 00^{\prime \prime} .00$ & & \\
\hline \multirow{4}{*}{$\begin{array}{l}\text { XLVIII Series- P-Q } \\
\text { Column }\end{array}$} & $44^{\circ} 00^{\prime} 36^{\prime \prime}$ & $22^{\circ} 52^{\prime} 27^{\prime \prime} .85$ & \multirow{4}{*}{100.649} & \multirow{4}{*}{100.162} \\
\hline & $44^{\circ} 00^{\prime} 36^{\prime \prime}$ & $23^{\circ} 00^{\prime} 00^{\prime \prime} .00$ & & \\
\hline & $44^{\circ} 06^{\prime} 00^{\prime \prime}$ & $22^{\circ} 52^{\prime} 27^{\prime \prime} .85$ & & \\
\hline & $44^{\circ} 06^{\prime} 00^{\prime \prime}$ & $23^{\circ} 00^{\prime} 00^{\prime \prime} .00$ & & \\
\hline \multirow{4}{*}{$\begin{array}{l}47 \text { Series- } \\
\text { P-Q Column }\end{array}$} & $44^{\circ} 06^{\prime} 00^{\prime \prime}$ & $22^{\circ} 52^{\prime} 27^{\prime \prime} .85$ & \multirow{4}{*}{100.498} & \multirow{4}{*}{97.457} \\
\hline & $44^{\circ} 06^{\prime} 00^{\prime \prime}$ & $23^{\circ} 00^{\prime} 00^{\prime \prime} .00$ & & \\
\hline & $44^{\circ} 11^{\prime} 24^{\prime \prime}$ & $22^{\circ} 52^{\prime} 27^{\prime \prime} .85$ & & \\
\hline & $44^{\circ} 11^{\prime} 24^{\prime \prime}$ & $23^{\circ} 00^{\prime} 00^{\prime \prime} .00$ & & \\
\hline
\end{tabular}

calculations for the two zones were made taking into account the particularities of each zone, as following:

\section{For Moldavia, Dobruja, and Wallachia east of the Zimnicea meridian}

Map sheets were delineated by the lines of a grid network. The rectangular coordinates for the corners of these sheet maps could be determined only through the index map, knowing that the dimensions of each sheet were $10 \mathrm{~km} \times 10 \mathrm{~km}$. The rectangular coordinates were transformed into geographical coordinates on the Bessel ellipsoid, using the Bonne projection inverse formula.

The area of a map sheet could not be directly determined because the map was not bound by the lines of meridians and parallels. Therefore, the area was calculated as the sum of infinitesimal trapezia whose sides were the lines of meridians and parallels, using the following equation (Soloviev, 1955):

$$
\begin{aligned}
& T=a^{2}\left(1-e^{2}\right) \frac{\left(\lambda_{2}-\lambda_{1}\right)^{\prime \prime}}{\rho^{\prime \prime}}\left[\left(\sin \varphi_{2}-\sin \varphi_{1}\right)+\frac{2 e^{2}}{3}\left(\sin ^{3} \varphi_{2}-\sin ^{3} \varphi_{1}\right)+\right. \\
& \left.\frac{3 e^{4}}{5}\left(\sin ^{5} \varphi_{2}-\sin ^{5} \varphi_{1}\right)+\frac{4 e^{6}}{7}\left(\sin ^{7} \varphi_{2}-\sin ^{7} \varphi_{1}\right)+\mathrm{K}\right] \\
& T= \\
& a^{2}\left(1-e^{2}\right) \frac{\left(c_{2}-\lambda_{2}\right)^{*}}{\rho^{4}}\left[\left(\sin \varphi_{2}-\sin \varphi_{1}\right)+\frac{2 e^{2}}{3}\left(\sin ^{3} \varphi_{2}-\sin ^{3} \varphi_{1}\right)+\frac{3 e^{4}}{5}\left(\sin ^{5} \varphi_{2}-\sin ^{5} \varphi_{1}\right)+\right. \\
& \left.\frac{4 e^{6}}{7}\left(\sin ^{7} \varphi_{2}-\sin ^{7} \varphi_{1}\right)+\cdots\right] \\
& \text { where: }
\end{aligned}
$$


Tab. 3. Rectangular coordinates for map sheet corners and their areas - $l_{E}$ interpolated (Wallachia west of the Zimnicea meridian and Oltenia)

\begin{tabular}{|c|c|c|c|c|}
\hline Map sheet & $\mathrm{j}$ & 1 & $\begin{array}{c}\text { Calculated area } \\
{\left[\mathrm{km}^{2}\right]}\end{array}$ & $\begin{array}{c}\text { Area writen on the } \\
\text { map }\left[\mathrm{km}^{2}\right] \\
\end{array}$ \\
\hline \multirow{4}{*}{$\begin{array}{l}49 \text { Series- } \\
\text { P-Q Column }\end{array}$} & $43^{\circ} 55^{\prime} 12^{\prime \prime}$ & $22^{\circ} 52^{\prime} 27^{\prime \prime} .85$ & \multirow{4}{*}{102.683} & \multirow{4}{*}{103.000} \\
\hline & $43^{\circ} 55^{\prime} 12^{\prime \prime}$ & $23^{\circ} 00^{\prime} 10^{\prime \prime} .6001$ & & \\
\hline & $44^{\circ} 00^{\prime} 36^{\prime \prime}$ & $22^{\circ} 52^{\prime} 27^{\prime \prime} .85$ & & \\
\hline & $44^{\circ} 00^{\prime} 36^{\prime \prime}$ & $23^{\circ} 00^{\prime} 10^{\prime \prime} .6001$ & & \\
\hline \multirow{4}{*}{$\begin{array}{l}\text { XLVIII Series- P-Q } \\
\text { Column }\end{array}$} & $44^{\circ} 00^{\prime} 36^{\prime \prime}$ & $22^{\circ} 52^{\prime} 27^{\prime \prime} .85$ & \multirow{4}{*}{100.158} & \multirow{4}{*}{100.162} \\
\hline & $44^{\circ} 00^{\prime} 36^{\prime \prime}$ & $22^{\circ} 59^{\prime} 59^{\prime \prime} .9481$ & & \\
\hline & $44^{\circ} 06^{\prime} 00^{\prime \prime}$ & $22^{\circ} 52^{\prime} 27^{\prime \prime} .85$ & & \\
\hline & $44^{\circ} 06^{\prime} 00^{\prime \prime}$ & 22०59’59”.9481 & & \\
\hline \multirow{4}{*}{$\begin{array}{l}47 \text { Series- } \\
\text { P-Q Column }\end{array}$} & $44^{\circ} 06^{\prime} 00^{\prime \prime}$ & $22^{\circ} 52^{\prime} 27^{\prime \prime} .85$ & \multirow{4}{*}{97.436} & \multirow{4}{*}{97.457} \\
\hline & $44^{\circ} 06^{\prime} 00^{\prime \prime}$ & $22^{\circ} 59^{\prime} 48^{\prime \prime} .3739$ & & \\
\hline & $44^{\circ} 11^{\prime} 24^{\prime \prime}$ & $22^{\circ} 52^{\prime} 27^{\prime \prime} .85$ & & \\
\hline & $44^{\circ} 11^{\prime} 24^{\prime \prime}$ & 22'59'48”.3739 & & \\
\hline
\end{tabular}
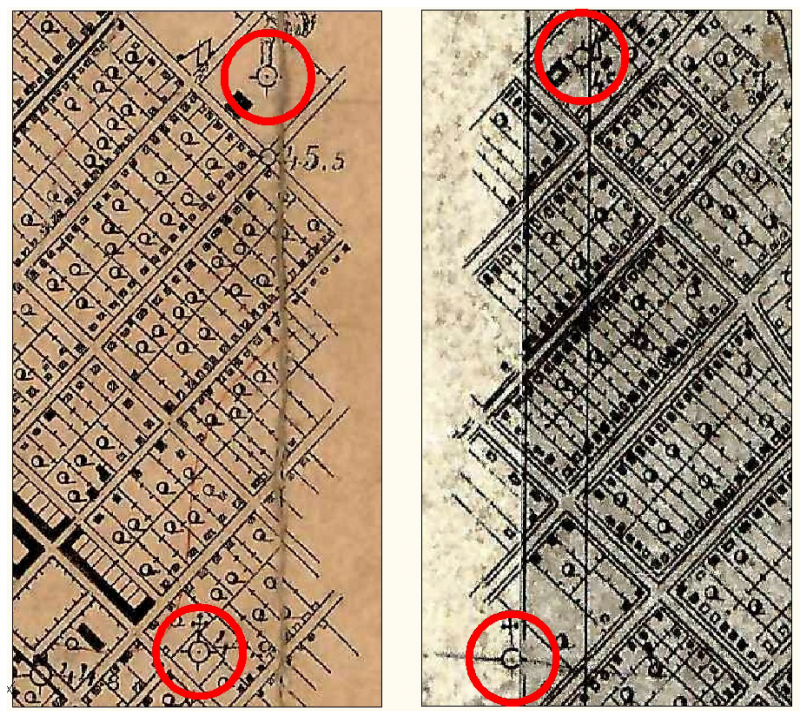

Fig. 6. The same detailes identified on the 49 Series $-P-Q$ Column and 48 Series- A'Column map sheets

$T$ - the area of a trapezium on ellipsoid whose sides were the $\mathrm{l}_{1}$ and $\mathrm{l}_{2}$ meridians, and the $\mathrm{j}_{1}$ and $\mathrm{j}_{2}$ parallels;

$a$ - the semimajor axis of the reference ellipsoid;

$e$ - the eccentricity of the ellipsoid;

$j_{1}, j_{2}$ - latitudes of parallels which bound the trapezium;

$l_{1}, l_{2}$ - longitudes of meridians which bound the trapezium.

\section{For Wallachia west of the Zimnicea meridian and Oltenia}

The neatline of these zone maps was formed by meridians and parallels arcs. The geographical coordinates on the Clarke ellipsoid for trapezia corners were determined using the index map. Afterwards, the trapezia area could be directly calculated using formula (1). The results obtained for the analyzed maps were presented in Table 2 .

The areas calculated for a $10 \mathrm{~km}$ x $10 \mathrm{~km}$ map sheet of the Moldavia, Dobruja and Wallachia east 

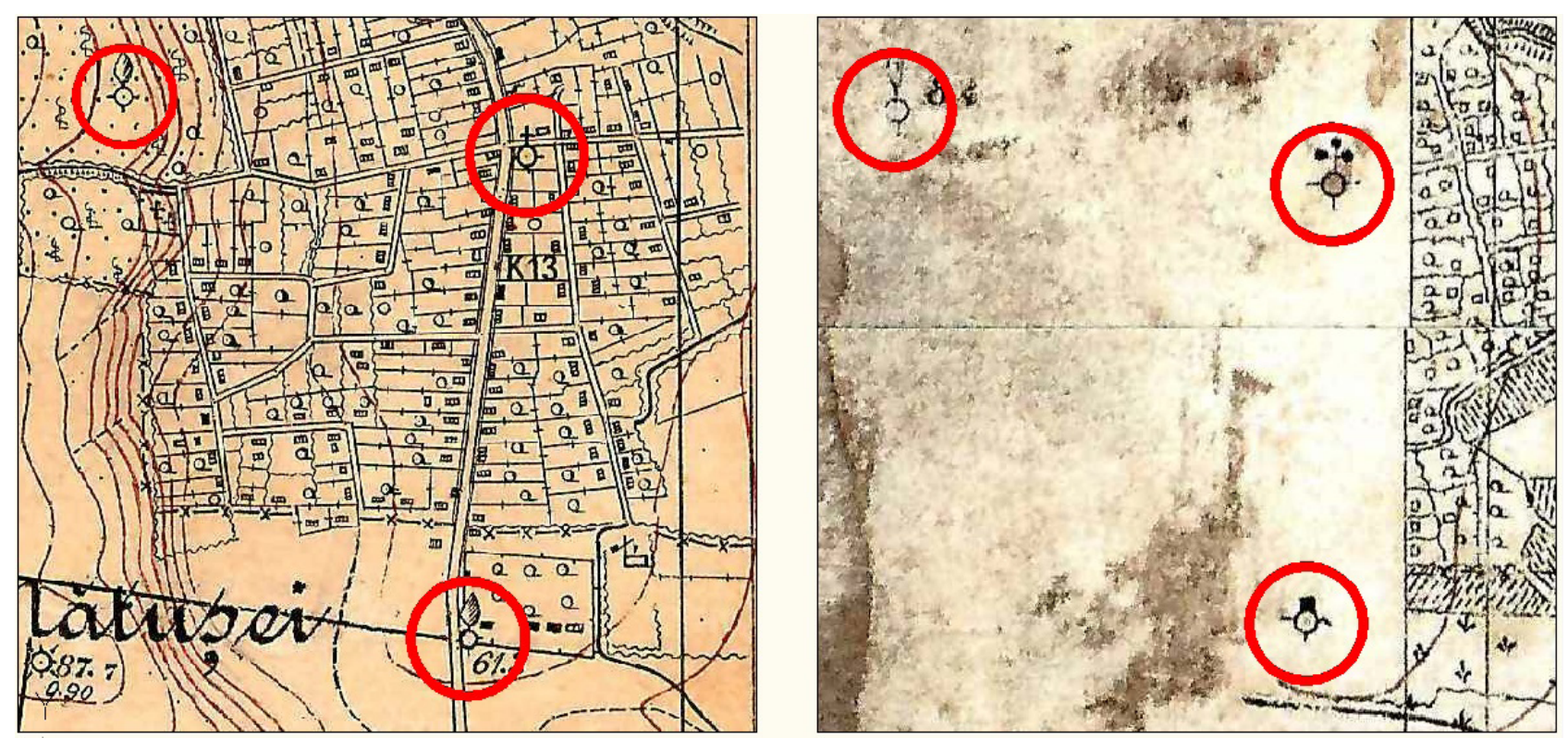

Fig. 7. The same detailes identified on the XLVIII Series- $P$ - $Q$ Column and XLVII Series- A'Column map sheets

of the Zimnicea meridian differed by $0.0005 \mathrm{~km}^{2}$ from the theoretical value, namely by $0.0005 \%$. The resulting difference was due to the precision of the applied calculation method.

Conversely, for trapezia from Wallachia west of the Zimnicea meridian and Oltenia, the difference between the calculated areas and those written on the maps were considerably larger. The following values were obtained: $2.201 \mathrm{~km}^{2}$ for 49 Series-P-Q Column, $-0.487 \mathrm{~km}^{2}$ for XLVIII Series-P-Q Column and $-3.040 \mathrm{~km}^{2}$ for 47 Series-P-Q Column. These results could be explained through the fact that other coordinates were used to calculate the areas. As the longitude on the western side was written on the maps, this meant that the eastern longitude was not $23^{\circ}$ as we previously surmised. In order to check this hypothesis, the longitude was interpolated at the eastern trapezia corners. Then, the corners' rectangular coordinates were calculated based on the interpolated values (Table

The resulting values were much closer to those written on the maps. The differences stemmed from differences in graphical measurement accuracy. Going further by analysing the details represented on the maps to the east and west of the Zimnicea meridian, one could notice that the elements drawn outside of the neatline of the eastern maps were found inside the neatline of the western maps (Fig. .6 and Fig. 7).
This suggested that the maps for Wallachia west of the Zimnicea meridian and Oltenia were not bordered at the east by the $\mathrm{l}=23^{\circ}$ meridian, but rather by the line that bordered the western part of the maps for Moldavia, Dobruja, and Wallachia east of the Zimnicea meridian. This line was not a meridian, but rather parallel to the OY axes of the Cartesian system used for Moldavia, Dobruja, and Wallachia east of the Zimnicea meridian.

\section{CONCLUSION}

The aim of the current paper was to centralise all information regarding the way in which the pseudoconical equal-area Bonne projection was used to realize $1: 20,000$ scale maps in our country from 1873 to 1917. This map projection was the first to be used in the creation of the topographic map of the country. These maps were also used for cadastre, since they featured information regarding properties. In addition, a way of establishing the nomenclature for these maps was also described and it also made a comparison between the calculated areas and those found written on these maps, proving that the maps situated to the west of the Zimnicea meridian were not actually bordered by the Zimnicea meridian, but by a line parallel to the OY axes of the Cartesian system used for the maps situated to the east of the same meridian.

These maps of our country made in the Bonne projection bear a strong historical value, not 
only in terms of cartography, but also cadastre, reflecting how properties were registered in the Kingdom of Romania.

Acknowledgments. The author would like to thank Col. Engr. Dan OLTEANU, Director of the "General de divizie Constantin Barozzi" Topographical Military Directorate, for the permission to use the original copy of the 48 Series- $A^{\prime}$ Column, XLVII Series- A' Column, 47 Series - P Column- Q Column, XLVIII Series- P Column- Q Column, 49 Series- $P$ Column- Q Column maps at the scale 1:20,000 and the $1: 1,600,000$ scale index map to support the aims of the current study.

\section{REFERENCES}

1. Bartos-Elekes, Z. (2010). Historic topographic map of Walachia and a possible digital application. In EGU General Assembly Conference Abstracts, Vol. 12, p. 9335.
2. Bartos-Elekes, Z., Timár, G., Imecs, Z., Magyari-Sáska, Z., (2013). Georeferencing the topographic map of Walachia (1855-1864). 8th International Workshop on Digital Approaches to Cartographic Heritage, At Rome, Italy, Volume: 8. Available at: http://beregovo.mapire.eu/ static/publications/romanian_bartoselekes_et_al.pdf. Accsessed 2015 June 23.

3. Buchholtzer, C., Rotaru, P. (1937). History of Cartography, Military Geographical Institute, pp. 94-95, 98, 104 (in Romanian).

4. Dragomir, V., Rotaru, M. (1986). Geodetic Testimonies, Military Publishing House, Bucharest, pp. 140-141 (in Romanian).

5. Munteanu, C. (2003). Mathematical Cartography, Matrix Rom Publishing House, Bucharest, pp. 190-191.

6. Rotaru, M., Anculete, G., Paraschiva, I. (1989). Evolution of military surveying conception in Romania, Military Publishing House, Bucharest, pp. 43-47, 54-55, 58-59, 66 (in Romanian).

7. Soloviev, M. D. (1955). Cartographic Projections, Military Publishing House, Bucharest, p. 19 (in Romanian). 